\title{
脳虚血による神経細胞死における恒常的活性型カルシニューリンの機能的役割
}

\author{
塩田倫史，福 永浩司*
}

\section{The Functional Roles of Constitutively Active Calcineurin in Delayed Neuronal Death after Brain Ischemia}

\author{
Norifumi SHIODA and Kohji FuKUnAGA* \\ Department of Pharmacology, Graduate School of Pharmaceutical Sciences, Tohoku University, \\ 6-3 Aramaki-Aoba, Aoba-ku, Sendai 980-8578, Japan
}

(Received August 28, 2010)

\begin{abstract}
Excessive $\mathrm{Ca}^{2+}$ elevation resulting from activation of NMDA and other $\mathrm{Ca}^{2+}$ channels is thought to play a pivotal role in pathologic events following brain ischemia. $\mathrm{The}^{2} \mathrm{Ca}^{2+}$ elevation directly triggers necrotic or apoptotic cell death through activation of $\mathrm{Ca}^{2+}$ /calmodulin (CaM) -dependent enzymes, including calcineurin (CaN). $\mathrm{CaN}, \mathrm{Ca}^{2+} / \mathrm{CaM}$ dependent serine/threonine protein phosphatase, partly mediates apoptosis associated with neuronal death. In a mouse middle cerebral artery occlusion (MCAO) model, calpain, a $\mathrm{Ca}^{2+}$-dependent cysteine protease, converted $\mathrm{CaN}$ to the constitutively active form of $48 \mathrm{kDa}$ in vivo. The calpain-induced CaN activation mediated delayed neuronal death through translocation of nuclear factor of activated T-cells (NFAT) and FKHR, a forkhead box class O family member (FOXO) into neuronal nuclei after brain ischemia. The FKHR activation occurred through decreased Akt activity with concomitant dephosphorylation by constitutively active CaN. Thereafter, FKHR formed a complex with CaN and in turn translocated into nuclei after brain ischemia. After nuclear translocation of NFAT and FKHR, the transcription factors stimulated expression of Fas-ligand by binding to its promoter regions. Taken together, constitutively active $\mathrm{CaN}$ mediates delayed neuronal death through Fas-ligand expression via up regulation of both NFAT and FKHR transcriptional activity in brain ischemia.
\end{abstract}

Key words — calcineurin; calpain; brain ischemia; Fas-ligand

\section{1. はじめに}

脳は，エネルギーの貯蔵がほとんどないにもかか わらず極めて活発な代謝を行っている臓器で, 多く の血流を要求し, 全体の 1/5-1/4 の酸素とブドウ糖 を消費する。 ${ }^{1,2}$ 一方, エネルギー供給の遮断に対し て極めて脆弱である．脳の虚血部位では短時間に再 灌流が起これば脳機能の回復が期待されるが，一定 時間以上の虚血が続くと不可逆的神経細胞障害が生

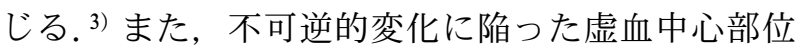
の周辺には虚血後も一時的に神経細胞が生存してい るペナンブラと呼ばれる部分が存在するが，一定時 間後に血流が回復しても一部はその後細胞死に至る ことが知られており, 遅発性神経細胞死と呼ばれて

東北大学大学院薬学研究科薬理学分野 (下980-8578 仙 台市青葉区荒巻字青葉 6-3)

*e-mail: fukunaga@mail.pharm.tohoku.ac.jp

本総説は, 日本薬学会第 130 年会シンポジウム S61 で 発表したものを中心に記述したものである.
(る. ${ }^{4)}$

脳虚血による神経細胞死の中で，ATP の枯渴に よるネクローシスとは異なる遅発性の選択的神経細 胞死の機序を説明する仮説として, 現在最も重視さ れている仮説は「グルタミン酸・カルシウム仮説」

である.この仮説はげっ歯類を用いた実験上の一過 性脳虚血後の海馬錐体神経細胞死のみならず，臨床 上のペナンブラ領域の神経細胞死にも当てはま る. ${ }^{5,6)}$ 細胞内 $\mathrm{Ca}^{2+}$ 濃度上昇は $\mathrm{Ca}^{2+}$ 依存性プロテ アーゼであるカルパインの活性化を起こし, 細胞骨 格タンパク質を分解する. カルパインは, $\mathrm{Ca}^{2+}$ に よって活性化される細胞内システインプロテアーゼ である. ${ }^{7)}$ 脳虚血障害においては，カルパインの基 質であり細胞骨格タンパク質であるフォドリンの分 解がみられ，カルパインが神経細胞膜構造を破壊す る. ${ }^{8)}$ タンパク質のリン酸化・脱リン酸化反応によ る細胞内情報伝達系に関しては, $\mathrm{Ca}^{2+}$ 依存性酵素 の中でも, $\mathrm{Ca}^{2+} /$ calmodulin $(\mathrm{CaM})$ 依存性一酸化 
窒素合成酵素 nitric oxide synthase（NOS）が脳虚血 における神経細胞死に重要な役割を果たすことが示 唆されている. NOS は CaM を介して活性化さ れ，一酸化窒素 nitric oxide（NO）を産生する。脳 虚血においては NO は持続的に産生され, ${ }^{9}$ ミトコ ンドリアの呼吸鎖の抑制や DNA 合成障害をもたら す。この際，NO は活性酸素であるスーパーオキシ ドラジカルと反応し, 最も神経毒性のあるパーオキ シナイトライトへと代謝され，組織障害を悪化させ る. ${ }^{10,11)}$ 一方, $\mathrm{Ca}^{2+} / \mathrm{CaM}$ 依存性脱リン酸化酵素で あるカルシニューリンも脳虚血における神経細胞死 に関与することが示唆されているが，その詳細なメ カニズムは明らかとされていない。本論文では脳虚 血におけるカルシニューリン活性化機構と神経細胞 死に関する研究について報告する。

2. 脳虚血におけるカルパインの活性化による恒 常的活性型カルシニューリンの産生について

脳虚血に陥ると, NMDA 受容体と電位依存性 $\mathrm{Ca}^{2+}$ チャネルの活性化により細胞外から過剩の $\mathrm{Ca}^{2+}$ が流入し, $\mathrm{Ca}^{2+}$ 依存性プロテアーゼであるカ ルパインが活性化されタンパク質の分解や変性が起 こる. ${ }^{12,13)}$ 変性タンパク質の蓄積は小胞体ストレス を引き起こし，アポトーシス関連遺伝子の誘導やミ トコンドリア依存性アポトーシスが起こる. ${ }^{14-16)} さ$ らに, $\mathrm{Ca}^{2+}$ は $\mathrm{Ca}^{2+}$ 依存性酵素の活性化を介して 神経細胞死を誘導する。特に, $\mathrm{Ca}^{2+} / \mathrm{CaM}$ 依存性 脱リン酸化酵素であるカルシニューリンは細胞死に おいて重要な役割を担っている。実際に，カルシニ ユーリン阻害薬である FK506 やシクロスポリン A は脳虚血やグルタミン酸神経毒性における神経細胞 死を抑制する. ${ }^{17-20)}$

カルシニューリンはカルシニューリン $\mathrm{A}$ とカル シニューリン B の 2 つのサブユニットからなる 2 量体であり，脳内タンパク質の約 $1 \%$ を占める神経 細胞に豊富に存在する脱リン酸化酵素である. ${ }^{21)}$ 力 ルシニューリン $\mathrm{A}$ は脱リン酸化酵素活性も持った 触媒領域と CaM 結合領域，カルシニューリン B 結 合領域，自己抑制領域を持つ。一方，カルシニュー リン B は 4 分子のカルシウムイオンが結合できる 構造を持っている. この 2 つのサブユニットは強固 に 1：1で結合しホロ酵素を形成している。 カルシ ニューリンは他の $\mathrm{Ca}^{2+} / \mathrm{CaM}$ 依存性酵素よりも低 いカルシウム濃度で活性化する。言い換えれば，カ
ルシウムイオンに対して感受性が高い. $\left.{ }^{22}\right) し か し ，$ 生体内では種々の内在性活性抑制タンパク質と複合 体を形成することにより活性が抑制されている. 23-26)

カルシニューリンは細胞死において重要な役割を 担っている. in vitro の実験では，カルシニューリ ンの活性化による NFAT の活性化は T 細胞のアポ

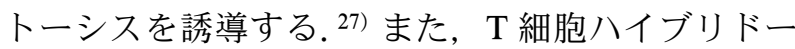
マにおける抗-CD3-抗体誘導性のアポトーシスは NFAT 活性化による細胞死因子 Fas-ligand の産生 によるものであることが示唆されている. ${ }^{28)}$ ヒト $\mathrm{T}$ 細胞においてもカルシニューリンを介した NFAT の脱リン酸化，それに伴う Fas-ligand の誘導はア ポトーシスを誘導する. ${ }^{29)}$ in vivo 実験においては, ラット線条体におけるメタンフェタミン誘導性の神 経細胞死においてカルシニューリンの脱リン酸化に よる NFAT の活性化はアポトーシスの引き金とな る. 30) しかしながら，カルシニューリンの虚血性神 経細胞死における役割は不明である.

脱リン酸化酵素カルシニューリンとタンパク質分 解酵素カルパインはいずれも $\mathrm{Ca}^{2+}$ 依存性に調節さ れ， $\mathrm{Ca}^{2+}$ によって活性化されるアポトーシスシグ ナルの開始点に位置している，これらは，それぞれ 神経細胞死などで重要な働きをするとされてきたも のの，これまでは互いに独立した系であると考えら れてきた。しかしながら，近年，神経毒であるカイ ニン酸処理による神経細胞死において, $\mathrm{Ca}^{2+}$ 上昇 により活性化されたカルパインがカルシニューリン の限定分解を引き起こし，その結果カルシニューリ ンは $\mathrm{Ca}^{2+}$ 非依存性の恒常的活性型に変化し細胞死 を引き起こすことが示唆された。 カルシニューリン に $\mathrm{Ca}^{2+} / \mathrm{CaM}$ が結合すると，A サブユニットの自 己抑制領域が触媒領域から離れ，カルシニューリン は活性化状態となる。この恋化は可逆的であり，生 理的な $\mathrm{Ca}^{2+}$ 上昇においてはカルシニューリンの活 性化反応は一過性である。しかし，カイニン酸誘発 性の神経細胞死では細胞内へ過剩なカルシウム上昇 が起こるとカルパインが活性化され，カルパインが $\mathrm{A}$ サブユニットの自己抑制領域を切断することに より，カルシニューリンは $48 \mathrm{kDa}$ の恒常的活性化 状態となる（Fig. 1)。しかしながら，脳虚血に伴 つて恒常的活性型カルシニューリンが産生されるの か，さらにカルシニューリンによってどのようなア ポトーシス関連遺伝子が誘導されるのか明らかとな 


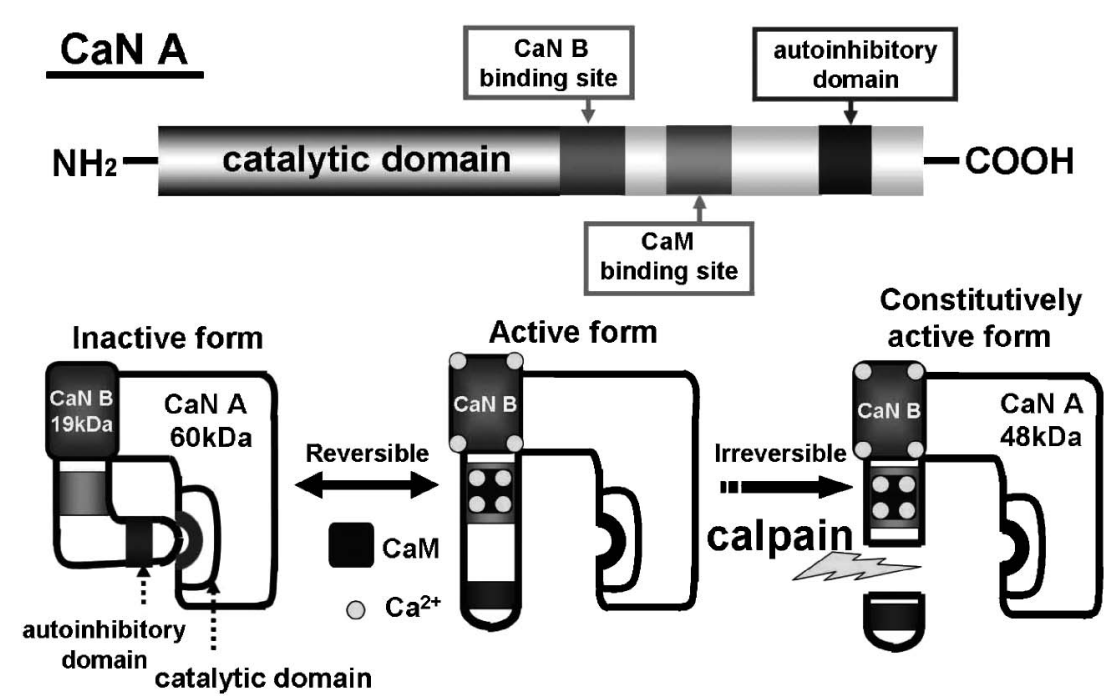

Fig. 1. Schematic Drawing of Calcineurin (CaN) Structure

っていない.

私達は，カルパインによるカルシニューリンの分 解が脳虚血によって起こるか検討するため，48 $\mathrm{kDa}$ カルシニューリンの産生について解析した. 脳虚血モデルは一過性中大脳動脈閉塞マウスを用い た. $150 \mathrm{kDa}$ フォドリン分解産物は脳虚血によって カルパイン特異的に分解され，産生するタンパク質 である. ${ }^{8)}$ 本研究ではカルパイン特異的 $150 \mathrm{kDa}$ 分 解産物を特異的に認識する抗体を用いて免疫ブロッ トした。 その結果, $150 \mathrm{kDa}$ フォドリン分解産物の 産生の増加によって脳虚血後カルパインが活性化す ることが確認され，その分解は特に脳虚血再灌流 0 -2 時間後に強く起こることが示唆された [Fig. 2 (a) ]. $150 \mathrm{kDa}$ フォドリン分解産物の産生と同じ時 間経過で，48 kDa カルシニューリンが脳虚血再灌 流 0-2 時間後に一過性に有意な上昇がみられた

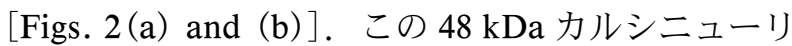
ンの産生がカルシニューリン活性上昇と相関するか 検討するため, 免疫沈降法による脱リン酸化酵素活 性測定を用いて $\mathrm{Ca}^{2+} / \mathrm{CaM}$ 存在下及び非存在下の

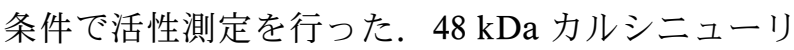
ンタンパク質の産生と一致して, $\mathrm{Ca}^{2+} / \mathrm{CaM}$ 非依 存性のカルシニューリン活性が脳虚血再灌流 2 時間 後をピークとして有意に上昇した $[$ Fig. 2(c) ].さ らに, $\mathrm{Ca}^{2+} / \mathrm{CaM}$ 依存性の総カルシニューリン活 性に関しても脳虚血再灌流 0-6 時間後に有意な増加 がタられた。

また，脳内で恒常的活性型カルシニューリンが
NFATc4 の核内移行に関与するか検討を行ったと ころ，NFATc4 は虚血再灌流 0-2 時間後に細胞質 画分において有意に減少し，核抽出物において増加 した。核抽出物における NFATc4 の増加は $48 \mathrm{kDa}$ カルシニューリンの産生の時間的経過と一致するこ とから，虚血条件において NFATc4 は恒常的活性 型カルシニューリンによって脱リン酸化されている 可能性が示唆された。さらに免疫染色の結果から も，脳虚血後 NFATc4 だけでなくカルシニューリ ンも核内移行することが示唆された. ${ }^{31)}$

3. 脳虚血におけるカルシニューリン活性化反応 に伴う NFAT と FKHR の脱リン酸化反応と Fasligand 誘導との関連性

神経細胞にはストレスに対する様々な防御機構が 備わつている。脳虚血においても Heat shock proteinなどの熱ショックタンパク質が誘導される. ${ }^{32)}$ また，脳虚血に伴ってチロシンキナーゼ系が充進す ることから，種々の細胞成長因子や増殖因子の受容 体の活性化反応が起こると考えられる．主要なもの としては脳由来神経栄養因子 (BDNF) が誘導され

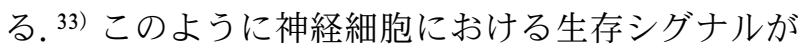
脳虚血において活性化されることは神経細胞のスト レスに対する防御反応と考えられている。私達はこ れまで生存シグナルの Akt（Protein kinase B）活性 の減少は脸虚血において神経細胞死を引き起こすこ とを示唆してきた. ${ }^{34-40)}$ Akt は細胞質において, Caspase-9, ${ }^{41)}$ class $\mathrm{O}$ members of the forkhead family $(\mathrm{FOXO}),{ }^{42)} \mathrm{Bad},{ }^{43)}$ などのアポトーシス誘導因 


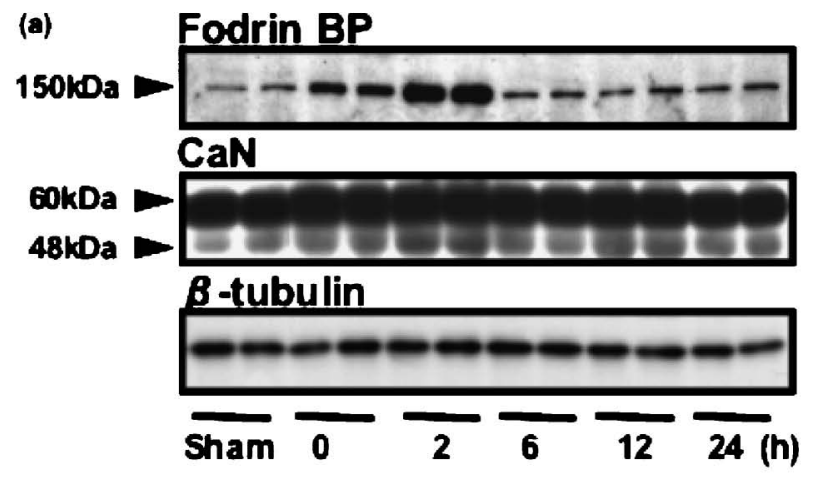

(b)

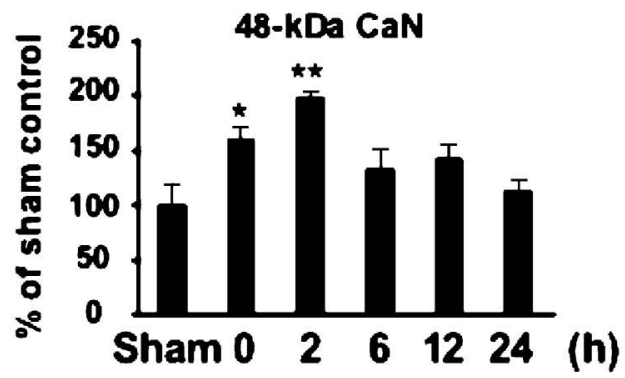

(c)

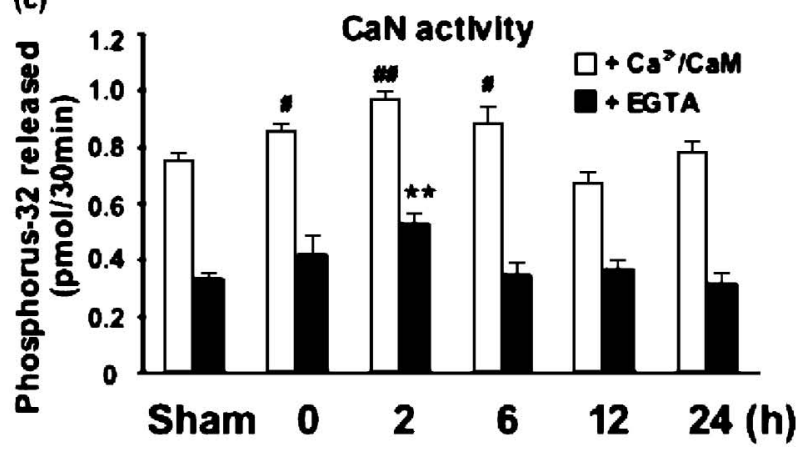

Fig. 2. Production of a 150-kDa Fodrin Breakdown Product and a $48-\mathrm{kDa}$ Constitutively Active $\mathrm{CaN}$ and Changes in $\mathrm{Ca}^{2+} / \mathrm{CaM}$-dependent and -independent CaN Activities after Ischemia

(a) Extracts obtained from the ipsilateral hemisphere subjected to MCAO were analyzed in immunoblotting using a specific antibody recognizing the $150-\mathrm{kDa}$ fodrin breakdown product (fodrin BDP), calcineurin $(\mathrm{CaN})$, and $\beta$-tubulin. Top, representative images of an immunoblot showing the $150-\mathrm{kDa}$ fodrin BDP. Middle, representative images of an immunoblot showing $60-$ and $48-\mathrm{kDa} \mathrm{CaN}$. Bottom, representative images of an immunoblot showing $\beta$-tubulin. (b) Quantitative analysis of cleaved $48-\mathrm{kDa}$ $\mathrm{CaN}$ was performed by densitometric scanning of immunoreactive bands. (c) The activities of $\mathrm{Ca}^{2+} / \mathrm{CaM}$-dependent (open bars) and $\mathrm{Ca}^{2+} / \mathrm{CaM}$-independent (closed bars) enzymes in extracts were measured. Values represent mean \pm S.E.M. of data from four independent experiments. ${ }^{*} p<0.05$, ${ }^{*} p<0.05 .{ }^{*} p<0.01,{ }^{* *} p<0.01$ vs. sham-operated animals (modified from Ref. 31).

子をリン酸化し，不活性化することで神経細胞の生 存を促進する. Akt の下流標的分子の FOXOs はフ オークヘッド型の DNA 結合ドメインを持つ転写因 子で，主にインスリンシグナル経路によって制御さ れる. FOXOファミリーの機能は細胞周期やアポ
トーシスの制御，DNA 修復，酸化ストレスに対す る防御など多岐にわたるが，その詳しい分子機構に ついてはほとんど明らかにされていない，FOXO ファミリーの中で, FOXO1 (forkhead in rhabdomyosarcoma; FKHR) は C. elegans の DAF-16 と相 同のフォークヘッド型転写因子で FKHR は核内で 細胞死誘導タンパク質である Fas-ligand や Bim を 誘導する転写因子である。FKHR はAktにより Ser-256 をリン酸化されることによって 14-3-3 タン パク質にトラップされ，核内移行とその転写活性が 阻害される. ${ }^{42,44,45)}$ 私達はこれまでの研究で, 脳虚 血において Akt 活性の減少により, なんらかの脱 リン酸化酵素によって FKHR（Ser-256）が脱リン 酸化され, 核内移行を促進し, 神経細胞死が引き起 こされることを明らかにした. ${ }^{34,35,40)}$ 以上の背景に 基づき, 脳虚血後 FKHR がカルパインによって活 性化された恒常的活性型カルシニューリンによって 脱リン酸化されるか, また, 恒常的活性型カルシニ ユーリンに脱リン酸化された NFAT と FKHR は Fas-ligand の発現に係わるか脳虚血モデルで検討し た.

Akt の活性化には Thr-308 と Ser-473 のリン酸化 が必須である. ${ }^{46)}$ マウス中大脳動脈閉塞モデルを用 いて Akt のリン酸化レベルを Ser-473 と Thr-308を 認識する抗体を用いて免疫ブロット法により検討を 行ったところ, Phospho-(P-) Akt（Ser-473）は虚 血再灌流 2 時間後に一過性に減少し，6 時間後には 有意に上昇した。一方, Akt（Thr-308）は虚血再 灌流 2-6 時間後にかけて有意に減少した。これらの 結果はマウス中大脳動脈閉塞モデルにおいて Akt 活性が虚血再灌流 2-6 時間後に減少することを示唆 している. また, Aktの下流の標的分子である PFKHR（Ser-256）についても検討を行つた。PFKHR（Ser-256）は虚血再灌流 2-6 時間後に有意 に減少した。このP-FKHR（Ser-256）の脱リン酸 化の時間的変化は P-Akt（Thr-308）の低下と一致 したことから, Akt 活性の減少は部分的に PFKHR（Ser-256）のリン酸化の減少に関与すると 考えられる。

次に, FKHR を脱リン酸化する脱リン酸化酵素 について検討を行つた. 恒常的活性型カルシニュー リンは虚血再灌流 2 時間後に最も活性化することを 示唆している. ${ }^{31)}$ さらに, カルシニューリン活性と 
P-FKHR（Ser-256）の脱リン酸化の時間的経過は ほぼ一致している，これらの理由から，恒常的活性 型カルシニューリンは P-FKHR（Ser-256）を脱リ ン酸化する酵素である可能性が考えられる。 カルシ ニューリンの特異的阻害剂である FK506（3 mg/ $\mathrm{kg}$, i.p.）を脳虚血 10 分前に前投与し, P-FKHR （Ser-256）に関して虚血再灌流 2 時間後に検討を行 ったところ，FK506 は部分的ではあるが，有意に FKHR の脱リン酸化を抑制した。

FKHR は脱リン酸化されると核内へ移行す る. ${ }^{40,47)}$ 一方, Shibasaki ${ }^{48)}$ らは骨肉種 U2OS 細胞 においてカルシニューリンが NFAT4 を脱リン酸化 し，複合体を形成して核内移行することを示した。 そこで，脳虚血後にカルシニューリンが FKHR と 複合体を形成するか検討を行った．偽手術群，ある いは脳虚血処置群のサンプルをカルシニューリン抗 体を用いて免疫沈降し，FKHR 抗体を用いて免疫 ブロットを行い，免疫複合体を同定した $[$ Fig. 3 (a)］．無処置群において，わずかに複合体が検出さ れた (lane 1)。一方, 虚血処置群ではカルシニュー リン/FKHR 複合体が顕著に増加した（lane 2)。し かしながら，FK506 処置マウス脳においてはこの 複合体の形成を抑制することができなかった（lane 3)。また，FKHR 抗体で免疫沈降を行い，カルシ ニューリン抗体で免疫ブロットを行ったところ [Fig. 3(b)]，無処置群において，60 kDa 付近にわ ずかに複合体が検出された（lane 1)。一方，虚血 群では， $60 \mathrm{kDa}$ 複合体が増加していることに加え て，48 kDa の複合体も検出された（lane 2)。これ らの結果は，脳虚血において $60 \mathrm{kDa}$ のならず, $48 \mathrm{kDa}$ 恒常的活性型カルシニューリンも FKHR と の複合体を形成することを示唆している．さらに， 脳虚血再灌流 2 時間後における海馬 CA1 領域の免 疫染色を行い，カルシニューリンと FKHR の局在 について検討した．カルシニューリンと FKHR は 偽手術群のマウス海馬において CA1 錐体細胞の細 胞質に局在がみられた。脳虚血再灌流 2 時間後にお いてはカルシニューリンと FKHR の局在が細胞質 だけでなく，核内においても強い染色性がみられた [Fig. 3 (c) ].さらに, 脳虚血群においてカルシニ ユーリンと FKHR の核内における共局在は同じ神 経細胞で多くみられた。これらの結果は，カルシニ ユーリンは FKHR と複合体を形成し，FKHR を活

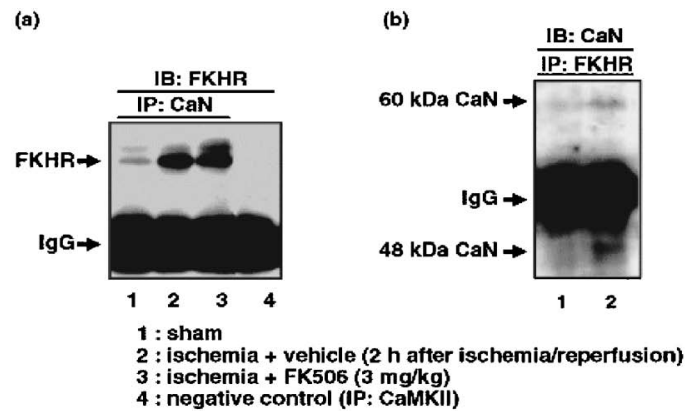

(c)

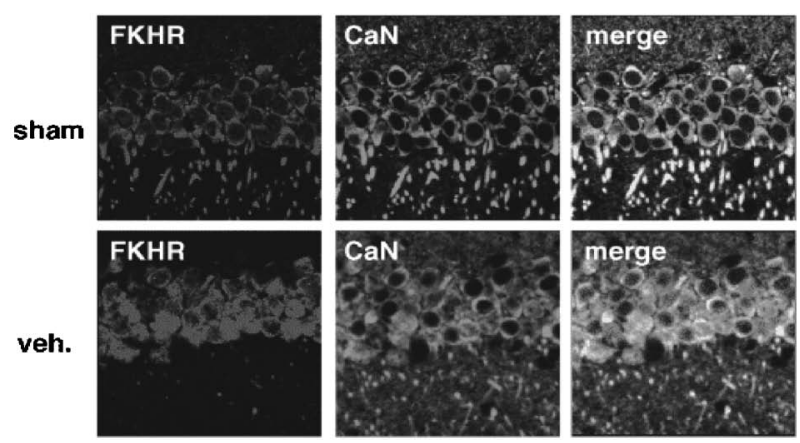

Fig. 3. CaN and FKHR Form a Complex, Which Translocates into Nuclei after Brain Ischemia

(a) Extracts were obtained from the ipsilateral hemisphere from shamoperated animals (lane 1) and ischemic animals subjected to MCAO for $2 \mathrm{~h}$ with vehicle (lane 2) or FK506 treatment (lane 3). The extracts underwent immunoprecipitation (IP) with the anti-CaN antibody, and immunoprecipitates were then analyzed by immunoblotting (IB) with anti-FKHR antibody. The negative control was immunoprecipitated with anti-CaMKII antibody (lane 4). (b) Extracts were obtained from sham-operated animals (lane 1) and ischemic animals subjected to MCAO for $2 \mathrm{~h}$ with vehicle (lane 2). The extracts underwent IP with the anti-FKHR antibody, and immunoprecipitates were then analyzed by IB with anti-CaN antibody. (c) Hippocampal slices from sham and ischemic animals $2 \mathrm{~h}$ after MCAO were double-stained with FKHR and CaN antibodies (modified from Ref. 49).

性化し核内移行して転写活性を上昇させることを示 している. ${ }^{49)}$

また，脳虚血後に核内移行した FKHR と NFAT が細胞死関連因子の発現に係わるか検討するため, Fas-ligand のプロモーター領域内のオリゴヌクレオ チドを用いてゲルシフトアッセイを行った。結果と して，FKHR と NFAT の両方が虚血再灌流 2-6 時 間後に Fas-ligand の転写活性を増加させることが 示された. ${ }^{49)}$

\section{4. おわりに}

これまでの結果を模式的に示す (Fig. 4)。脳虚 血により細胞内への過剩な $\mathrm{Ca}^{2+}$ 流入が起こり，ま た，Akt 活性が低下する．脳虚血による Akt 活性 低下のメカニズムは現在のところ不明であるが，力 ルシニューリンが Akt の脱リン酸化反応に関与す るという報告もある。 ${ }^{50)}$ 細胞内に過剰流入した 


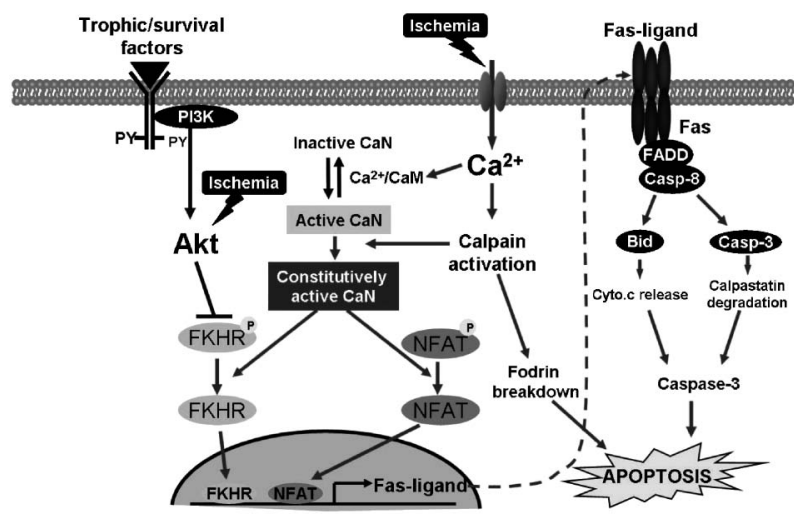

Fig. 4. Generation of Constitutively Active $\mathrm{CaN}$ and Fasligand Expression in Neurons after Brain Ischemia

$\mathrm{Ca}^{2+}$ は $\mathrm{Ca}^{2+}$ 依存性プロテアーゼであるカルパイ ンを活性化する。 また，同時にカルシニューリンも 活性型となる。ささに，活性化したカルパインは活 性型カルシニューリンを切断し，活性型カルシニ ユーリンを恒常的活性型とする．恒常的活性型カル シニューリンは FKHR と NFAT を脱リン酸化し, それらと複合体を形成し, 核内移行する。核内移行 した FKHR と NFAT はそれぞれ Fas-ligand プロ モーターに結合し，Fas-ligand の転写活性を上昇さ せる. Fas-ligand の発現上昇により，神経細胞死が 引き起こされる。また，脳虚血における FK506 の 神経保護効果のメカニズムには, カルシニューリン 活性を抑制することにより, FKHR と NFAT の脱 リン酸化を抑制すること，及びそれら転写因子によ り誘導される Fas-ligand の発現を抑制することが 神経細胞死の抑制に関与することが今回の研究で示 された。 さらに, 細胞の生存シグナルである Akt の上流を活性化する薬物である 4 価バナジウム化合 物 VO（OPT）が Fas-ligand などのアポトーシス誘 導因子発現を抑制することにより，マウス脳虚血に おける神経細胞死に対して抑制効果を持つことを明 らかとした. ${ }^{51)}$

本総説では，マウス中大脳動脈閉塞モデルにおけ る恒常的活性型カルシニューリンの産生機序とカル シニューリン活性化による Fas-ligand の誘導メカ 二ズムとその病態生理的意義に関して，いくつかの 新しい知見を述べた。細胞内における恒常的活性型 カルシニューリン産生によるカルシニューリン活性 上昇は，今回検討した脳虚血だけでなく，カルパイ ンが活性化するような神経変性疾患，例えば，グル
夕ミン酸誘発性神経毒, 脳挫傷, アルツハイマー病 などの病態においても起こることが予想され る. ${ }^{52-57)}$ 今回の研究が, 神経変性疾患の原因療法に 貢献でき，薬物治療の選択肢を広げる有用なものと なれば幸いである。

\section{REFERENCES}

1) Takeo S., Taguchi T., Tanonaka K., Miyake K., Horiguchi T., Takagi N., Fujimori K., Stroke, 23, 62-68 (1992).

2) Rami A., Agarwal R., Botez G., Winckler J., Brain Res., 866, 299-312 (2000) .

3) Ksiezak H. J., Gibson G. E., J. Neurochem., 37, 305-314 (1981).

4) Ikeda J., Nagashima G., Saito N., Nowak T. S. Jr., Joo F., Mies G., Lohr J. M., Ruetzler C. A., Klatzo I., Stroke, 21 (11 Suppl), III65III70 (1990).

5) Iadecola C., Trends Neurosci., 20, 132-139 (1997).

6) Barone F. C., Feuerstein G. Z., J. Cereb. Blood Flow Metab., 19, 819-834 (1999).

7) Saido T. C., Sorimachi H., Suzuki K., FASEB J., 8, 814-822 (1994).

8) Saido T. C., Yokota M., Nagano S., Yamaura I., Tani E., Tsuchiya T., Suzuki K., Kawashima S., J. Biol. Chem., 268, 25239-25243 (1993).

9) Hashiguchi A., Yano S., Morioka M., Hamada J., Ushio Y., Takeuchi Y., Fukunaga K., J. Cereb. Blood Flow Metab., 24, 271-279 (2004).

10) Aulak K. S., Miyagi M., Yan L., West K. A., Massillon D., Crabb J. W., Stuehr D. J., Proc. Natl. Acad. Sci. USA, 98, 12056-12061 (2001).

11) Bachschmid M., Thurau S., Zou M. H., Ullrich V., FASEB J., 17, 914-916 (2003).

12) Simon R. P., Swan J. H., Griffiths T., Meldurm B. S., Science, 226, 850-852 (1984).

13) Choi D. W., Koh J. Y., Peters S., J. Neurosci., 8, 185-196 (1988).

14) Ohta S., Furuta S., Matsubara I., Kohno K., Kumon Y., Sasaki S., J. Cereb. Blood Flow Metab., 16, 915-922 (1996).

15) Chen J., Nagayama T., Jin K., Stetler R. A., Zhu R. L., Graham S. H., Simon R. P., J. Neurosci., 18, 4914-4928 (1998). 
16) Abe T., Takagi N., Nakano M., Furuya M., Takeo S., Brain Res., 1009, 159-168 (2004).

17) Liu J., Farmer J. D. Jr., Lane W. S., Friedman J., Weissman I., Schreiber S. L., Cell, 66, 807-815 (1991).

18) Sharkey J., Butcher S. P., Nature, 22, 336-339 (1994).

19) Uchino H., Ishii N., Shibasaki F., Acta Neurochir. Suppl., 86, 105-111 (2003).

20) Uchino H., Minamikawa-Tachino R., Kristian T., Perkins G., Narazaki M., Siesjo B. K., Shibasaki F., Neurobiol. Dis., 10, 219-233 (2002)

21) Kincaid R. L., Balaban C. D., Billingsley M. L., Proc. Natl. Acad. Sci. USA, 84, 1118-1122 (1987)

22) Klee C. B., Ren H., Wang X., J. Biol. Chem., 273, 13367-13370 (1998).

23) Liu J. P., Sim A. T., Robinson P. J., Science, 265, 970-973 (1994)

24) Lai M. M., Hong J. J., Ruggiero A. M., Burnett P. E., Slepnev V. I., De Camilli P., Snyder S. H., J. Biol. Chem., 274, 2596325966 (1999).

25) Lai M. M., Luo H. R., Burnett P. E., Hong J. J., Snyder S. H., J. Biol. Chem., 275, 3401734020 (2000)

26) Dell'Acqua M. L., Dodge K. L., Tavalin S. J., Scott J. D., J. Biol. Chem., 277, 48796-48802 (2002).

27) Crabtree G. R., Cell, 96, 611-614 (1999).

28) Dhein J., Walczak H., Baumler C., Debatin K. M., Krammer P. H., Nature, 373, 438-441 (1995).

29) Latinis K. M., Norian L. A., Eliason S. L., Koretzky G. A., J. Biol. Chem ., 272, 3142731434 (1997)

30) Jayanthi S., Deng X., Ladenheim B., McCoy M. T., Cluster A., Cai N. S., Cadet J. L., Proc. Natl. Acad. Sci. USA, 102, 868-873 (2005).

31) Shioda N., Moriguchi S., Shirasaki Y., Fukunaga K., J. Neurochem., 98, 310-320 (2006).

32) Nowak T. S., Ikeda J., Nakajima T., Stroke, 21, 107-111 (1990).

33) Hsu C. Y., An G., Liu J. S., Xue J. J., He Y. Y., Lin T. N., Stroke, 24, I78-I81 (1993).

34) Kawano T., Fukunaga K., Takeuchi Y.,
Morioka M., Yano S., Hamada J., Ushio Y., Miyamoto E., J. Cereb. Blood Flow Metab., 21, 1268-1280 (2001).

35) Kawano T., Morioka M., Yano S., Hamada J., Ushio Y., Miyamoto E., Fukunaga K., J Cereb. Blood Flow Metab, 22, 926-934 (2002)

36) Yano S., Morioka M., Fukunaga K., Kawano T., Hara T., Kai Y., Hamada J., Miyamoto E., Ushio Y., J. Cereb. Blood Flow Metab., 21, 351-360 (2001).

37) Fukunaga K., Kawano T., J. Pharmacol. Sci., 92, 317-327 (2003).

38) Hasegawa Y., Hamada J., Morioka M., Yano S., Kawano T., Kai Y., Fukunaga K., Ushio Y., J. Cereb. Blood Flow Metab., 23, 10401051 (2003).

39) Hasegawa Y., Morioka M., Hasegawa S., Matsumoto J., Kawano T., Kai Y., Yano S., Fukunaga K., Kuratsu J., J. Pharmacol. Exp. Ther., 317, 875-881 (2006).

40) Fukunaga K., Ishigami T., Kawano T., J. Pharmacol. Sci., 98, 205-211 (2005).

41) Cardone M. H., Roy N., Stennicke H. R., Salvesen G. S., Franke T. F., Stanbridge E., Frisch S. Reed J. C., Science, 282, 1318-1321 (1998)

42) Brunet A., Bonni A., Zigmond M. J., Lin M. Z., Juo P., Hu L. S., Anderson M. J., Arden K. C., Blenis J., Greenberg M. E., Cell., 96, 857-868 (1999).

43) Datta S. R., Dudek H., Tao X., Masters S., Fu H., Gotoh Y., Greenberg M. E., Cell, 91 , 231-241 (1997).

44) Biggs W. H. 3rd., Meisenhelder J., Hunter T., Cavenee W. K., Arden K. C., Proc. Natl. Acad. Sci. USA., 96, 7421-7426 (1999).

45) Dijkers P. F., Medema R. H., Lammers J. W., Koenderman L., Coffer P. J., Curr. Biol., 10, 1201-1204 (2000).

46) Alessi D. R., Andjelkovic M., Caudwell B., Cron P., Morrice N., Cohen P., Hemmings B. A., EMBO J., 15, 6541-6551 (1996).

47) Rena G., Prescott A. R., Guo S., Cohen P., Unterman T. G., Biochem. J., 354, 605-612 (2001)

48) Shibasaki F., Price E. R., Milan D., Mckeon F., Nature, 25, 370-373 (1996).

49) Shioda N., Han F., Moriguchi S., Fukunaga 
K., J. Neurochem., 102, 1506-1517 (2007) .

50) Park C. H., Kim Y. S., Kim Y. H., Choi M. Y., Yoo J. M., Kang S. S., Choi W. S., Cho G. J., Brain Res., 1234, 148-157 (2008) .

51) Shioda N., Ishigami T., Han F., Moriguchi S., Shibuya M., Iwabuchi Y., Fukunaga K., Neuroscience, 148, 221-229 (2007).

52) Lee K. S., Frank S., Vanderklish P., Arai A., Lynch G., Proc. Natl. Acad. Sci. USA., 88, 7233-7237 (1991).

53) Saito K., Elce J. S., Hamos J. E., Nixon R. A., Proc. Natl. Acad. Sci. USA., 90, 26282632 (1993).
54) Hajimohammadreza I., Raser K. J., Nath R., Nadimpalli R., Scott M., Wang K. K., J. Neurochem., 69, 1006-1013 (1997).

55) Nakagawa T., Zhu H., Morishima N., Li E., Xu J., Yankner B. A., Yuan J., Nature, 403, 98-103 (2000).

56) Wu H. Y., Tomizawa K., Oda Y., Wei F. Y., Lu Y. F., Matsushita M., Li S. T., Moriwaki A., Matsui H., J. Biol. Chem., 6, 4929-4940 (2004).

57) Liu F., Grundke-Iqbal I., Iqbal K., Oda Y., Tomizawa K., Gong C. X., J. Biol. Chem., 280, 37755-37762 (2005). 